\title{
Countermovements in Europe? A Polanyian perspective
}

\author{
Martin Seeliger (martin.seeliger@uni-flensburg.de) \\ Europa-Universität Flensburg, Germany \\ Bernd Sommer (bernd.sommer@uni-flensburg.de) \\ Europa-Universität Flensburg, Germany
}

Recently, the developments of neoliberal globalization which have emerged since the early 1970s have been framed as a wave of disembedding of the market in the Polanyian sense (see, for instance, Burawoy, 2013 or Dale, 2016). As expected according to Polanyian theory, the marketization of the "fictitious commodities" (Polanyi, 2001, 137) nature, labour and money has led to their degradation and thus the undermining of the very foundations of production and exchange: Today, one can witness the destruction of vital ecosystems on a global scale (Rockström et al., 2009), the (re)emergence of living and working conditions that systematically fall below established social and human right standards (Sassen, 2014), as well as a deep ongoing financial crisis (Tooze, 2018).

Based on his historical investigation, Polanyi states that phases of economic liberalization and free trade have been systematically complemented by political countermovements functioning as a "self-protection of society" (Polanyi, 2001, 136). This has become known as Polanyi's concept of the 'double movement': "What we think of as market societies or 'capitalism' is the product of both of these movements; it is an uneasy and fluid hybrid that reflects the shifting balance of power between these contending forces" (Block, 2008, 2). At the same time, critics of such an understanding of a necessary interplay between market forces and counteractions highlight the superiority of global markets over attempts to regulate the economy. As Streeck $(2012,315)$ puts it, under conditions of neoliberal globalization, "[t]here simply is no ,primacy of politics" under capitalism, and cannot be". Similarly, Burawoy (2013) diagnoses the nonappearance of a cross-border countermovement as resulting from the political weaknesses of actors at the international level (also see Fraser, 2013). Similarly, with reference to Caporaso and Tarrow's (2009) idea of a countermovement manifesting itself in the course of European integration, Höpner and Schäfer (2010) identify an inherent weakness of transnational actors in the EU, due to its institutional heterogeneity.

Following these considerations, this special issue poses the question, if and how far the neoliberal globalization of the somewhat last 40 years has caused a countermovement in the Polanyian sense. What are the reasons that, despite years of protest and the emergence of new social movements, no countermovement has appeared? Or should sociologists take on a different perspective? Does the interplay of various measures of international labour regulation aggregate into what can be viewed as a global countermovement? Are there touching points between the agendas of labour and other social movements, adding up to a broader countermovement? Does the on-going crisis in the EU and create an opportunity for new alliances among political actors? And do these initiatives aim at a re-nationalization or Europeanization of measures of re-embedding?

Besides resistance movements from the political left, neoliberal globalization has also provoked "various forms of religious and ethnic fundamentalism that are often reactionary in their political preferences" (Block, 2008, 5). According to Michael Burawoy, historically, 
the countermovement "included fascism and Stalinism as well as the New Deal and social democracy" (Burawoy, 2013, 38). And Nancy Fraser notes "that social protection is often ambivalent, affording relief from the disintegrative effects of markets upon communities, while simultaneously entrenching domination within and among them" (Fraser 2013: 129). From this perspective, the rise of right-wing populist parties and politicians in Europe and the US has recently been described as reactionary or authoritarian countermovements against marketization. Is this an appropriate application of the Polanyian concept of countermovement? Or do racism and nationalism in Europe stem from a tradition that cannot only by conceptualised as a mere reaction to current or historic forms of marketization? As there are various possibilities of how political actors can react to globalization, and what can we learn about the inherent tendencies within such reactions?

Our special issue applies a Polanyian framework in order to explore recent (European) countermoves against the marketization of the fictitious commodities labour, money and nature. Additionally, we discuss right-wing populism as a likely 'reactionary countermovement' to marketization. Every contribution on the respective countermovement is commented by an expert in the specific field. This organizing principle leads to the following structure of this special issue:

\begin{tabular}{|c|c|c|c|c|}
\hline Topic \& Title & Author & Page & Comment & Page \\
\hline $\begin{array}{l}\text { "Trade union politics } \\
\text { as a countermove- } \\
\text { ment? A Polaniyan } \\
\text { perspective" }\end{array}$ & $\begin{array}{l}\text { Martin Seeliger } \\
\text { (Europa-Universität } \\
\text { Flensburg) }\end{array}$ & $5-23$ & $\begin{array}{l}\text { Edward Webster } \\
\text { (University of } \\
\text { Witwatersrand) }\end{array}$ & $24-28$ \\
\hline $\begin{array}{l}\text { "The fictitious com- } \\
\text { modification } \\
\text { of money and the } \\
\text { Euro experiment" }\end{array}$ & $\begin{array}{l}\text { Maja Savevska } \\
\text { (Nazarbayev Univer- } \\
\text { sity) }\end{array}$ & $29-42$ & $\begin{array}{l}\text { Jonah Stuart } \\
\text { Brundage } \\
\text { (UC Berkeley) }\end{array}$ & $43-47$ \\
\hline $\begin{array}{l}\text { "The EU emissions } \\
\text { trading scheme: pro- } \\
\text { tection via commodi- } \\
\text { fication?" }\end{array}$ & $\begin{array}{l}\text { Christopher M. Rea } \\
\text { (Brown University \& } \\
\text { The Ohio State Uni- } \\
\text { versity) }\end{array}$ & $48-73$ & $\begin{array}{l}\text { Arild Vatn } \\
\text { (Norwegian Univer- } \\
\text { sity of Life Sciences) }\end{array}$ & $74-77$ \\
\hline $\begin{array}{l}\text { "Rise of right-wing } \\
\text { populism in the Eu- } \\
\text { rope of today- out- } \\
\text { lines of a socio-theo- } \\
\text { retical exploration" }\end{array}$ & $\begin{array}{l}\text { Hans-Jürgen Bieling } \\
\text { (University of } \\
\text { Tübingen) }\end{array}$ & $78-91$ & $\begin{array}{l}\text { Floris Biskamp } \\
\text { (University of } \\
\text { Tübingen) }\end{array}$ & $92-102$ \\
\hline
\end{tabular}

These full papers and their respective comments that focus on various (European) countermovements against marketization of society and nature are followed by two further research articles applying a Polanyian framework: Based on qualitative interviews, in "The Economy for the Common Good: a European countermovement against the destructive impacts of laissez-faire capitalism?" Klara Stumpf and Bernd Sommer (both Europa-Universität Flensburg) deal with a current civic action movement that developed after the financial crisis of 2009 in Austria and expanded since to various European states. Subsequently, Michael Brie (Rosa Luxemburg Foundation) in "Karl Polanyi and discussions on a renewed socialism" opens a transformative perspective on status quo capitalism. The 
focus of this special issue on Polanyian countermovements is completed by a "Review of recent literature on Polanyi" by Moritz Müller (Ruhr University Bochum).

Not directly linked to the focus of this issue on European countermovements are the articles "The reality of exclusive solidarity" by Silke van Dyk and Stefanie Graefe (both Friedrich-Schiller-Universität Jena), "Between clarity and disorientation" by Ludger Pries (Ruhr-Universität Bochum) and "Keep it straight and simple, also with respect to migration" by Andreas Nölke (Goethe-Universität Frankfurt). All three pieces are responses to Wolfgang Steeck's article "Between Charity and Justice: Remarks on the Social Construction of Immigration Policy in Rich Democracies" that has been published previously in Culture, Practice \& Europeanization (CPE) in 2018. This rather voluminous issue of CPE finally concludes with an interview of Hauke Brunkhorst (Europa-Universität Flensburg) Donatella della Porta (European University Institue) and Fritz W. Scharpf (Max Planck Institute for the Study of Societies) on European Integration (by Monika Eigmüller \& Martin Seeliger, both Europa-Universität Flensburg).

\section{References}

Block, F. (2008). Polanyi's double movement and the reconstruction of Critical Theory. Revue Interventions économiques. Vol. 38/2008. http://interventionseconomiques.revues.org/274 (last accessed 12.01.2019).

Burawoy, M. (2013). Marxism after Polanyi. In M. Williams \& V. Satgas (Eds.), Marxism in the 21st Century (34-52). Johannesburg, South Africa: Wits University Press.

Abawa, G. (2018). SocioCultural dimensions of food: The case of Teff. In A. Beyene (Ed.), Agricultural Transformation in Ethiopia. State Policy and Smallholder Farming (100-118). London: Zed Books.

Caporaso, J. \& Tarrow, S. (2009). Polanyi in Brussels: Supranational institutions and the transnational embedding of markets. International Organization, 63, 593-620.

Dale, G. (2016). Reconstructing Karl Polanyi. Excavation and critique. London: Pluto Press.

Fraser, N. (2013). A triple movement? Parsing the politics of crisis after Polanyi. New Left Review, Vol. 81, 119-131.

Höpner, M. \& Schäfer, A. (2010). Polanyi in Brussels? embeddedness and the three dimensions of European economic integration (MPIfG Discussion Paper 10/8).

Polanyi, K. (2001 [1944]). The Great Transformation. The political and economic origins of our time. Boston: Beacon Press.

Rockström, J., Steffen, W., Noone, K., Persson, Å., Stuart Chapin III, F., Lambin, E.F., Lenton, T.M., Scheffer, M., Folke, C., Schellnhuber, H-J., Nykvist, B., de Wit, C., Hughes, T., van der Leeuw, S., Rodhe, H., Sörlin, S., Snyder, P.K., Costanza, R., Svedin, U., Falkenmark, M., Karlberg, L., Corell, Robert W., Fabry, V.J., Hansen, J., Walker, B., Liverman, D., Richardson, K., Crutzen, P., Foley, J.A. (2009). A safe operating space for humanity. Nature, Vol. 461, 472-475. 
Sassen, S. (2014). Expulsions. Brutality and complexity in the global economy. Cambridge, MA: Harvard University Press.

Streeck, W. (2012). On Fred Block, varieties of what? Should we still be using the concept of Capitalism? In J. Go (Ed.), Political Power and Social Theory (311-321). Emerald Group Publishing Limited.

Tooze, A. (2018). Crashed. How a decade of financial crises changed the world. New York: Viking. 